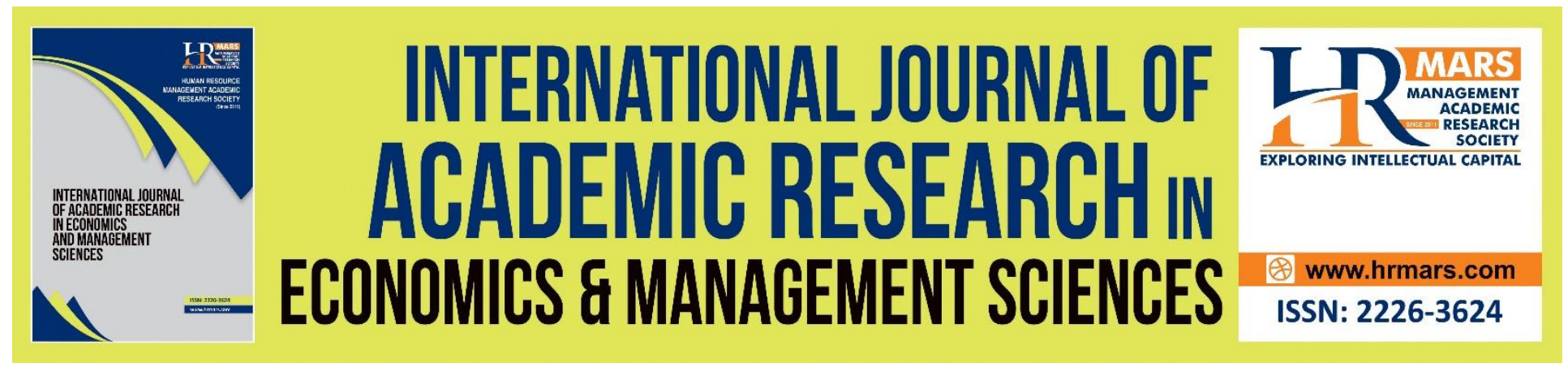

\title{
Does Income Shock During Covid-19 Make Any Difference on Consumption among Malaysian Household
}

Nordianah Binti Jusoh @ Hussain, Khairunnisa Abd Samad, Nik Rozila Nik Mohd Masdek, Nurhayati Abdul Rahman, Wan Musyirah Wan Ismail, Bushra Mohd Zaki

To Link this Article: http://dx.doi.org/10.6007/IJAREMS/v9-i3/8007

DOI: 10.6007/IJAREMS/v9-i3/8007

Received: 05 July 2020, Revised: 26 July 2020, Accepted: 30 August 2020

Published Online: 21 September 2019

In-Text Citation: (Jusoh @ Hussain, et. al., 2020)

To Cite this Article: Jusoh @ Hussain, N. B., Abd Samad, K., Masdek, N. R. N. M., Abdul Rahman, N., Ismail, W. M. W., \& Zaki, B. M. (2020). Does Income Shock During Covid-19 Make Any Difference on Consumption among Malaysian Household. International Journal of Academic Research in Economics and Management Sciences. 9(3), 21-30.

\section{Copyright: @ 2020 The Author(s)}

Published by Human Resource Management Academic Research Society (www.hrmars.com)

This article is published under the Creative Commons Attribution (CC BY 4.0) license. Anyone may reproduce, distribute, translate and create derivative works of this article (for both commercial and non-commercial purposes), subject to full attribution to the original publication and authors. The full terms of this license may be seen at: http://creativecommons.org/licences/by/4.0/legalcode

Vol. 9, No. 3, 2020, Pg. 21 - 30

Full Terms \& Conditions of access and use can be found at http://hrmars.com/index.php/pages/detail/publication-ethics 


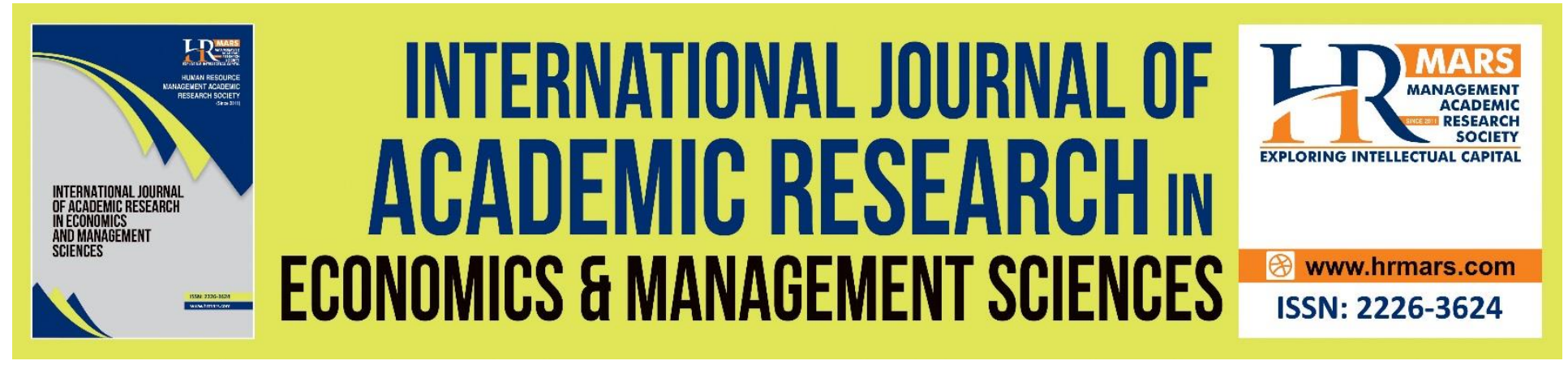

\title{
Does Income Shock During Covid-19 Make Any Difference on Consumption among Malaysian Household
}

\author{
Nordianah Binti Jusoh @ Hussain ${ }^{\mathrm{a}}$, Khairunnisa Abd Samad ${ }^{\mathrm{b}}$, Nik \\ Rozila Nik Mohd Masdekc, Nurhayati Abdul Rahman ${ }^{\mathrm{d}}$, Wan \\ Musyirah Wan Ismaile, Bushra Mohd Zaki ${ }^{\dagger}$ \\ a,b,c Universiti Teknologi Mara Kampus Alor Gajah, Melaka, d,eUniversiti Teknologi Mara Kampus \\ Bandaraya Melaka, Melaka, fUniversiti Teknologi Mara, Puncak Alam \\ Email: dianah642@uitm.edu.my, khairunsamad@uitm.edu.my
}

\begin{abstract}
This study aims to explore the difference of income shock on consumption among the Malaysian household during the Covid-19. The study conducts online survey and the finding reveals that this cohort are facing the greatest challenges of unemployment risk such as their job opportunities will be severely curtailed by the contraction of the job market, having income shock to their comparatively lower incomes, hence struggle to finance their expenses as the consumption increases. Nevertheless, our descriptive analysis basically shows that the income shock is merely temporary and significantly make difference on the consumption for the affected Malaysian household. The research also concludes that MCO resulted in unaffected income for most of the respondents, which could be said that MCO does not have a significant effect on the financial situation and financial burden for the majority of Malaysian. The findings can help the policymakers to formulate the suitable formulation.
\end{abstract}

Keywords: Income Shock, Consumption, Covid-19, Chi-square.

\section{Introduction}

During Covid-19, there are two stages of Movement Order in Malaysia in response to the COVID19 pandemic; Movement Control Order (MCO) from18 March-9 June 2020 and Recovery Movement Control Order (RMCO)-10 June onwards. The Department of Statistic Malaysia (DOSM) conducted a survey between March 23 to 31 March, during the second week of RMO phase one, showed half of those self-employed reported to be out of work while up to a third said their income dropped by some 90 per cent from the 170,000 workers polled. The statistics shows alarming concerns that the vulnerable households are experiencing income shocks. Moreover, DOSM survey 2020 showed half of them have savings enough only to last two weeks, while only 28 per cent said they had enough to last two months. Another worrying statistic raised 
the concerns among the policy makers. In addition, Labor Force Survey (LFS, 2020) announced that, as Covid-19 takes toll, Malaysia's unemployment rate rises to 5 percent in April. The average expenditure on household consumption during the MCO is expected to decrease by 48 per cent (DOSM, 2020). Expectations about household spending are influenced by income shocks, but not by financial wealth shocks. Nonetheless, mostly affected by the income shock were selfemployed. They face the highest risk of unemployment and their job opportunities will be severely curtailed by the contraction of the job market, and with their comparatively lower incomes, many will struggle to feed their families. Motivated by the scenario discussed above, this paper aims to explore the income shocks and consumption among the Malaysian household in pre and post Covid-19.

The novelty of this study is emphasising the situation on income shock and consumption during this critical situation of Covid-19 using the latest survey conducted during this pandemic of Covid-19. In fact, the study contributes to the current studies by focusing the definition of income shock in terms of unemployment and salary cut among the respondents by extending the life cycle and permanent income hypotheses. The findings of study shows that that there is significance difference of consumption for the affected respondents during the pandemic. Hence, the empirical findings of the study significantly assist the policy maker to consider careful policy formulation in enhancing the country's economic development through the household income and consumption. The paper proceeds in the following way. Section II briefly review previous studies on the related theories. Section III briefly explain the methodology employed. Section IV presented the findings and concludes the summary of the study in section V.

\section{Literature Review}

The theoretical underlay which can explain the behavior of household consumption is reflected in the life cycle and permanent income hypotheses (Ando \& Modigliani, 1963; Friedman, 1957; Modigliani \& Brumberg, 1954). They explained, individuals save at an early age, accumulate wealth in the middle age, and dis-save at retirement days. They contended their belief which asserted that the levelling of household consumption maximized their function over time using both initial income and expected future income. The hypothesis emphasized that the Malaysian household will increase their expenditure, save more at middle life and withdraw their saving during retirement days. A lower than expected financial earnings motivated household borrowing. Nevertheless, in cases of an unexpected increase in income or during their most productive working days, the household would attempt to save.

Income shock is an unpredictable or unexpected event that can affected the activities of consumer spending and economy. It is affected because of job loss, unemployment and salary cutting. According to Stevens (1997) and Been et al. (2020), the effect of income shock because of job loss can be faced by individual multiple times in their life cycle. They will suffer even more in the future due to debt burden and increase in expenditure. Income shock during pandemic covid-19 is getting worse because people are losing their job. This leads to reduction in consumption. There was a research done stated that $34 \%$ reduction in consumption was due to job loss shock which equal to income shock (Been et al., 2020). 
Income shock also occurs to those individuals that are not being employed. According to Farrell et al. (2016), the huge impact of income drops and being unemployed is decline in spending. Another financial unpreparedness that leads to income shock is salary cutting. During the lockdown due to pandemic of Covid - 19 in Malaysia, some employees experienced salary cutting as many businesses were closed and struggled to pay rent and utility bills (Zahiid, 2020). According to Reuters (2020), the staff and management have mutually agreed to cut staff's salaries by $15 \%$ to $75 \%$ based on seniority during the outbreak. This will give adverse impact on the income and spending of those who are vulnerable to income shock. They will struggle more because a lot of expenses commitment need to be settled.

\section{Methodology}

The research study is an analytical research study to explore the income shock on consumption behaviour among the Malaysian household in pre and post Covid-19. A simple non-probability random sampling was used as the basis in the selection of the respondents during the critical stage of pandemic Covid-19 with the help of a structured questionnaire. The survey was distributed using online survey between June 25, 2020 and July 5, 2020 to peninsular and nonpeninsular Malaysia. The survey asked questions related to the viability of the job in pre and post pandemic and their levels of spending. The final sample size was 134, with representation from a wide random of the Malaysian population. Chi-square test has been used for statistical analysis. The demographic profiles of the respondents are described in Tables 1-4.

\section{Data Analysis and Results}

This section comprises four subsections. We discuss several demographic characteristics in first subsection, followed by the income level in pre and post in response to Covid-19 in second subsection and income level in respect to consumption in pre and post in response to Covid-19 in third subsection. The final subsection discusses income shock and consumption. In order to study the impact income shock on consumption behaviour in pre and post Covid-19 based on one hypothesis are formulated and analysed. Chi-square $(\chi 2)$ test of independence has been applied to all the tests of hypotheses using significance level, $\alpha=0.05$.

\section{Demographic Characteristic}

In this study customer's demographic characteristic were determined by age, sex, education level, monthly income, occupation and number of households. Based on this survey, total of respondents are 134 individuals, there are about 18 individuals are within age 25 to 30 years old, 51 individuals are within 31 to 35 years old and 65 individuals are ranged between 36 and 40 years old (table 1). 
INTERNATIONAL JOURNAL OF ACADEMIC RESEARCH ECONOMICS AND MANAGEMENT SCIENCES Vol. 9, No. 3, 2020, E-ISSN: 2226-3624 @ 2020 HRMARS

Table 1: Age versus Income Shock during MCO (March - May 2020)

\begin{tabular}{|c|c|c|c|c|c|}
\hline & \multicolumn{3}{|c|}{ Age } & \multirow{2}{*}{ Total } \\
\hline & & $25-30$ & $31-35$ & $36-40$ & \\
\hline \multirow{2}{*}{$\begin{array}{l}\text { How you } \\
\text { described your } \\
\text { salary since the } \\
\text { outbreak of the } \\
\text { COVID-19 and } \\
\text { CPP outbreaks }\end{array}$} & $\begin{array}{l}\text { Income } \\
\text { unaffected }\end{array}$ & 13 & 33 & 51 & 97 \\
\hline & $\begin{array}{l}\text { Income } \\
\text { affected }\end{array}$ & 5 & 18 & 14 & 37 \\
\hline & Total & 18 & 51 & 65 & 134 \\
\hline
\end{tabular}

107 individuals are female while others are males (table 2). As for educational level of frequency, 15 (11.1 percent) and 25 (18.7 percent) of the respondents hold Sijil Pelajaran Malaysia (SPM) and Diploma respectively. The highest percentage is recoded at 41.8 percent for Degree's holders and followed by master's degree holders with 26.9 percent from the total respondents. Meanwhile only 2 (1.5 percent) of respondents are PhD holder (table 3).

Table 2: Gender versus Income Shock during MCO (March - May 2020)

\begin{tabular}{|c|c|c|c|c|}
\hline & \multicolumn{2}{|c|}{ Gender } & \multirow{2}{*}{ Total } \\
\hline & & Male & Female & \\
\hline \multirow{2}{*}{$\begin{array}{l}\text { How you } \\
\text { described your } \\
\text { salary since the } \\
\text { outbreak of the } \\
\text { COVID-19 and } \\
\text { CPP outbreaks }\end{array}$} & $\begin{array}{l}\text { Income } \\
\text { unaffected }\end{array}$ & 19 & 78 & 97 \\
\hline & $\begin{array}{l}\text { Income } \\
\text { affected }\end{array}$ & 8 & 29 & 37 \\
\hline & Total & 27 & 107 & 134 \\
\hline
\end{tabular}

Table 3: Education Level versus Income Shock during MCO (March - May 2020)

\begin{tabular}{|c|c|c|c|c|c|c|c|}
\hline & \multicolumn{5}{|c|}{ Education Level } & \multirow{2}{*}{ Total } \\
\hline & & SPM & Diploma & ljazah & Masters & PhD & \\
\hline \multirow{2}{*}{$\begin{array}{l}\text { How you } \\
\text { described your } \\
\text { salary since the } \\
\text { outbreak of the } \\
\text { COVID-19 and } \\
\text { CPP outbreaks }\end{array}$} & $\begin{array}{l}\text { Income } \\
\text { unaffected }\end{array}$ & 8 & 14 & 43 & 32 & 0 & 97 \\
\hline & $\begin{array}{l}\text { Income } \\
\text { affected }\end{array}$ & 7 & 11 & 13 & 4 & 2 & 37 \\
\hline & Total & 15 & 25 & 56 & 36 & 2 & 134 \\
\hline
\end{tabular}

Most respondents have income range between RM2000 and RM6000 which categorized under middle income group in (M40). This demographic is demonstrating in Table 4 as below: 
INTERNATIONAL JOURNAL OF ACADEMIC RESEARCH ECONOMICS AND MANAGEMENT SCIENCES Vol. 9, No. 3, 2020, E-ISSN: 2226-3624 @ 2020 HRMARS

Table 4: Monthly Income versus Income Shock during MCO (March - May 2020)

\begin{tabular}{|c|c|c|c|c|c|c|}
\hline & \multicolumn{4}{|c|}{ Monthly Income } & \multirow[t]{2}{*}{ Total } \\
\hline & & $\begin{array}{c}0< \\
2000\end{array}$ & $\begin{array}{c}2000< \\
4000\end{array}$ & $\begin{array}{c}4000< \\
6000\end{array}$ & $>6000$ & \\
\hline \multirow{2}{*}{$\begin{array}{l}\text { How you } \\
\text { described your } \\
\text { salary since } \\
\text { the outbreak } \\
\text { of the COVID- } \\
19 \text { and CPP } \\
\text { outbreaks }\end{array}$} & $\begin{array}{l}\text { Income } \\
\text { unaffected }\end{array}$ & 13 & 27 & 28 & 29 & 97 \\
\hline & $\begin{array}{l}\text { Income } \\
\text { affected }\end{array}$ & 12 & 9 & 9 & 7 & 37 \\
\hline & Total & 25 & 36 & 37 & 36 & 134 \\
\hline
\end{tabular}

\section{Consumption Versus Income Shock During Mco Covid-19 (March-May 2020)}

Null hypothesis 1: Having less spending are independent of income shock.

The table depicts three categories of consumption; less than RM2000, between RM2000 and RM4000 and more than RM4000. Our study categorizes the group of respondents into Income affected and income unaffected during the MCO Covid-19 (March-May 2020). So, the income affected refers to household that received partly of their income, salary cut or do not receive any income. The following Table 5 elucidated the results of the respondents towards categories of consumption. On applying Chi-square $(\chi 2)$ test, we get $P$ valued as 0.023 , at the confident level 0.05 , which indicates that there is sufficient evidence to reject the null hypothesis. We, therefore, can conclude that having less spending are dependent of income shock during MCO. Majority of unaffected income group can spend within up to RM4000. The group who affected are less than the group unaffected which are 97 and 37 respondents respectively. Although the group affected has small percentage (28\%) but majority of them spend less RM 2000.

Table 5: Cross table of Income Shock versus consumption during MCO (March - May 2020)

\begin{tabular}{|c|c|c|c|c|c|}
\hline & \multicolumn{3}{|c|}{$\begin{array}{l}\text { What is the monthly (RM) } \\
\text { household spending during MCO } \\
\text { Covid-19 (March-May 2020)? }\end{array}$} & \multirow[t]{2}{*}{ Total } \\
\hline & & $0<2000$ & $\begin{array}{c}2000< \\
4000\end{array}$ & $>4000$ & \\
\hline \multirow{2}{*}{$\begin{array}{l}\text { How you described } \\
\text { your salary since } \\
\text { the outbreak of } \\
\text { the COVID-19 and } \\
\text { CPP outbreaks }\end{array}$} & $\begin{array}{l}\text { Income } \\
\text { unaffected }\end{array}$ & 42 & 41 & 14 & 97 \\
\hline & $\begin{array}{l}\text { Income } \\
\text { affected }\end{array}$ & 25 & 11 & 1 & 37 \\
\hline \multicolumn{2}{|r|}{ Total } & 67 & 52 & 15 & 134 \\
\hline \multicolumn{2}{|r|}{$\chi 2$ P-value } & \multicolumn{4}{|r|}{0.023} \\
\hline
\end{tabular}




\section{Consumption Versus Income Shock During Mco Covid-19 (June-August 2020)}

Null hypothesis 1: Having less spending are independent of income shock.

The table depicts three categories of consumption; less than RM2000, between RM2000 and RM4000 and more than RM4000. Our study categorizes the respondents into two groups income earner namely Income affected and income unaffected during the MCO Covid-19 (June-August 2020). So, the income affected refers to household that received partly of their income, salary cut or do not receive any income. The following Table 6 elucidated the results of the respondents towards categories of consumption. On applying Chi-square $(\chi 2)$ test, we get $P$ valued as 0.481 , at the confident level 0.05 , which indicates that there is no evidence to reject the null hypothesis. We, therefore, can conclude that having less spending are independent of income shock during the RMCO. Majority of unaffected income group can spend within up to RM2000. The group who affected are less than the group unaffected which are 28 and 106 respondents respectively. Although the group affected has small percentage (21\%) but majority of them spend less RM2000. Still, the stimulus package may help the affected income online with Hanspal et al. (2020) government policies will concentrate on supporting households at the bottom of their income distribution, whose wages have been hit hardest by the current recession and are close to zero.

Table 6: Cross table of Income Shock versus consumption during MCO (June - August 2020)

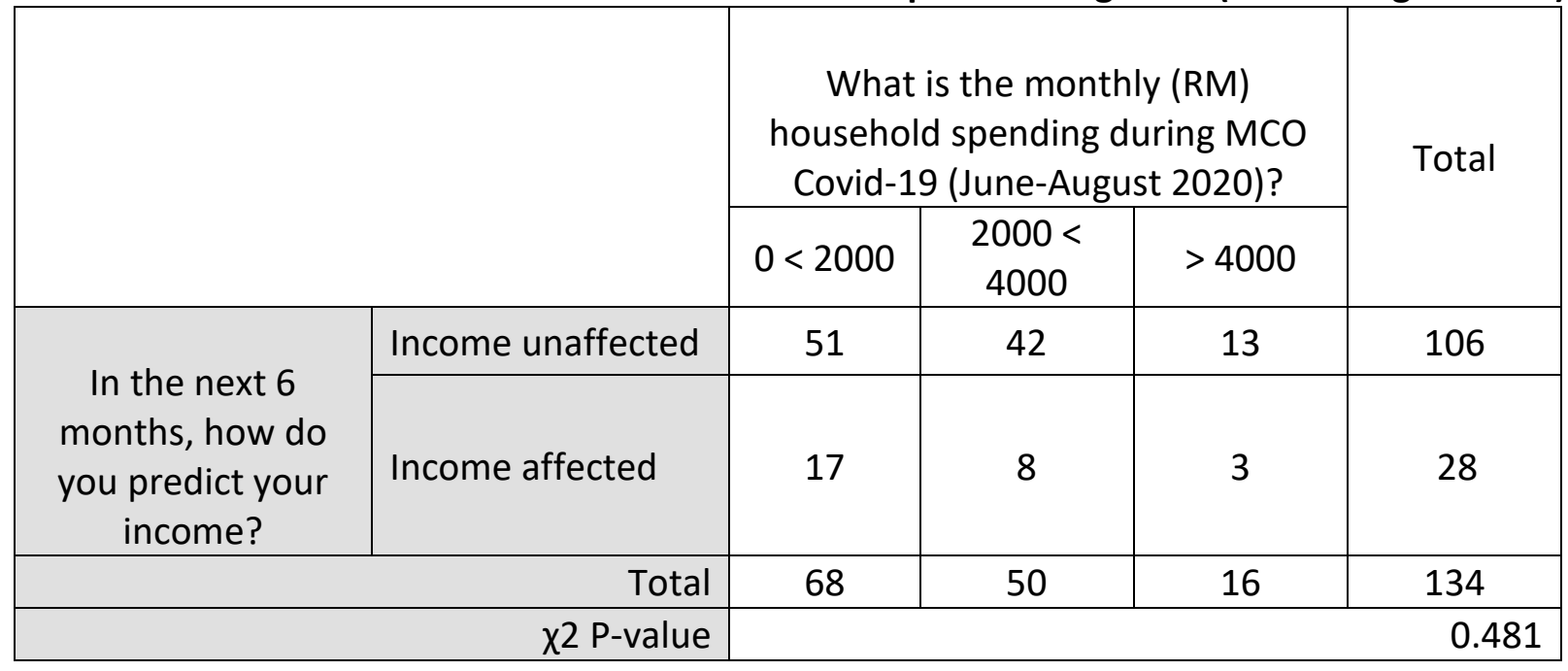

\section{Conclusion}

The objective of this study is to explore the difference of income shock on consumption among the Malaysian household during the Covid-19. An analysis of the research concludes that the income shock makes differences on consumption during MCO among Malaysian household. They are majority of the respondents agree that MCO have not affected their salary. It is based on a sample of 134 respondents from variety of demographic background. In terms of age, majority respondents form category of age $36-40$ years, which is $48.5 \%$ who are mostly have a lot of commitment in this age, agree that there is unaffected income since MCO begin because most of the respondents are government civil servant. The study might be useful to policymakers in understanding the household spending behavior in response to income shock and reflect the 
current policy and sustain or formulate the suitable planning for future research and development as well as finding effective strategies for household be part of agent in stimulating the country's economic growth. Besides, future study can look forward to investigating the relationship between incomes and spending in wider scope of sample of respondents and taken into consideration of household indebtedness.

\section{Acknowledgement}

This work was supported by the Geran Teja Dalaman 2020 (GDT2020-23) UiTM Cawangan Melaka.

\section{References}

Andersen, A. L., Hansen, E. T., Johannesen, N., \& Sheridan, A. (2020). Consumer responses to the COVID-19 crisis: Evidence from bank account transaction data. Working Paper, 2020. Available at SSRN 3609814.

Ando, A., \& Modigliani, F. (1963). The" life cycle" hypothesis of saving: Aggregate implications and tests. The American economic review, 53(1), 55-84.

Baker, S. R., Farrokhnia, R. A., Meyer, S., Pagel, M., \& Yannelis, C. (2020). How does household spending respond to an epidemic? consumption during the 2020 covid-19 pandemic (No. w26949). National Bureau of Economic Research.

Barr, D. G., and Campbell, J. Y. (1997). Inflation, Real Interest Rates, and the Bond Market: A Study of U.K. Nominal and Index-Linked Government Bond Prices. Journal of Monetary Economics, 39, 361-383.

Been, J., Suari-Andreu, E., Knoef, M., \& Alessie, R. (2020). Consumption responses to unemployment shocks. Netspar Academic Series. DP01/2020-005

Bernama.(2020). Perkeso pantau kehilangan pekerjaan semasa krisis Covid-19. Sinar Harian. Retrieved from https://www.sinarharian.com.my/article/80591/BERITA/Nasional/Perkeso-pantaukehilangan-pekerjaan-semasa-krisis-Covid-19

Bernama. (2020) Socso: Job losses in Malaysia increased by 42pc in Q1 due to Covid-19. Malay Mail. Retrieved from https://www.malaymail.com/news/malaysia/2020/06/03/socsojob-losses-in-malaysia-increase-by-42pc-in-q1-due-to-covid-19/1872211

Bernama. (2020. COVID-19: 3 daripada 5 hilang pekerjaan berusia bawah 40. Berita Harian. Retrieved from https://www.bharian.com.my/berita/nasional/2020/06/700243/covid19-3-daripada-5-hilang-pekerjaan-berusia-bawah-40

Bianco, C. A., \& Bosco, S. M. (2002). Ethical issues in credit card solicitation of college studentsThe responsibilities of credit card issuers, higher education, and students. Teaching Business Ethics, 6(1), 45-62.

Chan, K. (2006). Young consumers and perception of brands in Hong Kong: A qualitative study. Journal of Product \& Brand Management, 15(7), 416-426.

Chen, H., Qian, W., \& Wen, Q. (2020). The Impact of the COVID-19 Pandemic on Consumption: Learning from High Frequency Transaction Data. Available at SSRN 3568574.

Coibion, O., Gorodnichenko, Y., \& Weber, M. (2020). The cost of the covid-19 crisis: Lockdowns, macroeconomic expectations, and consumer spending (No. w27141). National Bureau of Economic Research. 
INTERNATIONAL JOURNAL OF ACADEMIC RESEARCH ECONOMICS AND MANAGEMENT SCIENCES

Vol. 9, No. 3, 2020, E-ISSN: 2226-3624 @ 2020 HRMARS

Department of Statistic Malaysia. (2020). Retrieved from https://www.dosm.gov.my/v1/uploads/files/covid-

19/Analisis_Survei_Khas_Kesan_COVID-19_Kepada_Ekonomi_dan_Individu-

Laporan_Penuh.pdf

Department of Statistic Malaysia (2020). Retrieved from

https://www.dosm.gov.my/v1/index.php?r=column/cthemeByCat\&cat=100\&bul_id=R0

9wdGZSektvNmw5T1VCeVphNXRqdz09\&menu_id=TE5CRUZCblh4ZTZMODZIbmk2aWRR QT09

Eze, U., \& Lee, C. (2012, 6 26). Consumers' Attitude towards Advertising. International Journal of Business and Management, 7(13).

Farrell, D., Ganong, P., Greig, F., \& Noel, P. (2016). Recovering from Job Loss: The Role of Unemployment Insurance. JPMorgan Chase \& Co., September.

Fetzer, T., Hensel, L., Hermle, J., \& Roth, C. (2020). Coronavirus perceptions and economic anxiety. Review of Economics and Statistics, 1-36.

Friedman, M. (1957). A Theory of the Consumption Function. Princeton: Princeton University Press.

Ganong, P., Noel, P. (2019). Consumer Spending during Unemployment: Positive and Normative Implications. American Economic Review 2019, 109(7): 2383-2424 https://doi.org/10.1257/aer.20170537

Gelman, M., Kariv, S., Shapiro, M. D., Silverman, D., \& Tadelis, S. (2015). How individuals smooth spending: Evidence from the 2013 government shutdown using account data. Cambridge, MA: National Bureau of Economic Research.

Grønhøj, A. (2007). The consumer competence of young adults: A study of newly formed households. Qualitative Market Research, 10(3), 243-264.

Hanspal, T., Weber, A., \& Wohlfart, J. (2020). Income and wealth shocks and expectations during the covid-19 pandemic. Cesifo Woking Papers No. 8244

Loke, Y. J. (2016). Financial preparedness for income shock among Malaysians. Malaysian Journal of Economic Studies, 53(2), 279-295.

Malaysian Institute of Economic Research. (2020). Retrieved from https://www.mier.org.my/the-economic-impacts-of-covid-19/

Modigliani, F., \& Brumberg, R. (1954). Utility analysis and the consumption function: An interpretation of cross-section data. Franco Modigliani, 1(1), 388-436.

Molanorouzi, K., Khoo, S., \& Morris, T. (2015). Motives for adult participation in physical activity: type of activity, age, and gender. BMC public health, 15(1), 66.

Nga, J., Yong, L., \& Sellappan, R. (2011). The influence of image consciousness, materialism and compulsive spending on credit card usage intentions among youth. Young Consumers, 12(3), 243-253.

Ngui, Y., Chew, E. (2020). Genting Malaysia is said to cut $15 \%$ of its workforce. The Edge Market. https://www.theedgemarkets.com/article/genting-malaysia-mulling-3000-jobcuts-\%E2\%80\%94-report

Penman, S., \& Mcneill, L. (2008). Spending their way to adulthood: Consumption outside the nest. Young Consumers, 9(3), 155-169.

Pirog, S., \& Roberts, J. (2007). Personality and credit card misuse among college students: The mediating role of impulsiveness. Journal of Marketing Theory and Practice, 15(1), 65-77. 
Reuters. (2020). Malaysia's AirAsia founders not taking salary; staff accepts up to 75\% pay cut. The Economic Times.

https://economictimes.indiatimes.com/news/international/business/malaysias-airasiafounders-not-taking-salary-staff-accepts-up-to-75-pay-cut/articleshow/75104956.cms

Stevens, A. H. (1997). Persistent effects of job displacement: The importance of multiple job losses. Journal of Labor Economics, 15(1, Part 1), 165-188.

Twenge, J., \& Campbell, S. (2008). Generational differences in psychological traits and their impact on the workplace. Journal of Managerial Psychology, 23(8), 862-877.

Vespa, J. (2017). The changing economics and demographics of young adulthood: 1975-2016 (pp. 1-23). US Department of Commerce, Economics and Statistics Administration, US Census Bureau.

Welsh, B., \& Cheng, C. (2020). Malaysia's youth on the frontlines of the COVID crisis. Institute of Strategic and International Studies (ISIS) Malaysia. Retrieved at https://www.isis.org.my/wp-content/uploads/2020/04/Youth-unemploymentfrontline.pdf

Yingjiao, Y. (2008). The influence of public self-consciousness and materialism on young consumers' compulsive buying. Young Consumers, 9(1), 37-48.

Zahiid, S. J. (2020). Covid-19 lockdown: Malaysians with pay cuts struggled more than jobless to pay bills, survey found. Malay Mail.

https://www.malaymail.com/news/malaysia/2020/06/14/covid-19-lockdown-

malaysians-with-pay-cuts-struggled-more-than-jobless-to-p/1875359 